\title{
Daniel Jurewicz
}

Państwowa Wyższa Szkoła Zawodowa we Włocławku

e-mail: daniel.jurewicz@pwsz.wloclawek.pl

\section{Magdalena Zioło}

Uniwersytet Szczeciński

e-mail: magdalena.ziolo@usz.edu.pl

\section{ZRÓWNOWAŻONE ZARZĄDZANIE DLUGIEM PUBLICZNYM \\ NA TLE EWOLUCJI PARADYGMATU FINANSÓW}

\section{SUSTAINABLE PUBLIC DEBT MANAGEMENT \\ ON THE BACKGROUND OF EVOLUTION \\ OF THE FINANCIAL PARADIGM}

DOI: $10.15611 / \mathrm{pn} .2018 .532 .15$

JEL Classification: H63, F65, E6

Streszczenie: $\mathrm{W}$ artykule przedstawiono teoretyczne ujęcie zarządzania długiem publicznym z perspektywy finansów zrównoważonych. Wskazano na różnice w rozumieniu zrównoważonego zarządzania długiem publicznym $\mathrm{w}$ tradycyjnym i zrównoważonym paradygmacie finansów. Posłużono się krytyczną analizą literatury, metodą indukcji i dedukcji, metodą porównań i uogólnień oraz metodą syntezy. W wyniku przeprowadzonych analiz wykazano, że finanse zrównoważone w sposób kompleksowy opisują i objaśniają złożoność kategorii zarządzania długiem publicznym w stosunku do tradycyjnego paradygmatu finansów.

Słowa kluczowe: zrównoważone finanse, dług publiczny, zarządzanie długiem.

Summary: The article presents a theoretical approach to public debt management from the perspective of balanced finances. Differences in the understanding of sustainable public debt management in the traditional and balanced financial paradigm were pointed out. The authors use a critical analysis of literature, the method of induction and deduction, method of comparisons and generalizations, and synthesis method. As a result of the conducted analyses, it was shown that balanced finance in a comprehensive manner describes and explains the complexity of the public debt management category in relation to the traditional finance paradigm.

Keywords: sustainable finance, public debt, debt management. 


\section{Wstęp}

Perspektywa ostatniego kryzysu finansowego wzmocniła potrzebę odmiennego spojrzenia na finanse, a w szczególności na problem zarządzania długiem publicznym. Jednym z paradygmatów, który zyskał znaczenie w obliczu doświadczeń kryzysu, okazał się paradygmat finansów zrównoważonych. Tradycyjny paradygmat finansów, osadzony w teorii efektywnego rynku i dążący do maksymalizowania przepływów pieniężnych okazał się zawodny z uwagi na wąsko zarysowane ramy obserwacji, wykluczające z analiz czynnik społeczny i środowiskowy. Neoklasyczna teoria perspektywy finansowej, popierana przez S. Friedmana (1970), F. Modiglianiego i M. Millera (1958), M. Jensena i W. Mecklinga (1976) utrzymuje, że odpowiedzialność społeczna wykracza poza obowiązki dyrektorów korporacji i powinna być wyłącznie w sferze zainteresowań rządu. Pojawia się zatem pytanie dotyczące perspektywy poznawczej finansów w kontekście dopasowania do trójfilarowego paradygmatu zrównoważonego rozwoju.

Ostatnio, w szczególności w perspektywie postkryzysowej zaczęło dominować przekonanie o potrzebie podejścia holistycznego w finansach, co oznacza konieczność włączenia do modelu finansów i analiz finansowych zmiennych ekonomicznych i pozaekonomicznych. Trójwymiarowość modelu finansów zrównoważonych umożliwia wyeliminowanie ograniczeń modelu finansów tradycyjnych skutkujących zniekształconą wyceną ryzyka, kosztów, kapitału oraz wartości, wpływającą na motywacje indywidualne i instytucjonalne po stronie zarządzających finansami.

W kontekście ewolucji paradygmatu finansów w kierunku finansów zrównoważonych szczególnie istotna jawi się potrzeba zmiany podejścia do zarządzania długiem publicznym. Nadmierne zadłużenie jest jednym z wiodących wyzwań dla finansów publicznych po kryzysie 2008+. Wydaje się, że finanse zrównoważone dysponują mechanizmem i instrumentarium, które skutecznie przeciwdziała zjawisku nadmiernego, destrukcyjnego zadłużenia.

Celem artykułu jest wskazanie na różnice w podejściu do zarządzania długiem publicznym na tle ewolucji paradygmatu finansów w kierunku finansów zrównoważonych w perspektywie postkryzysowej.

\section{Zarządzanie długiem w sektorze publicznym}

Zarządzanie, stanowiące koordynowanie wykorzystywania posiadanych zasobów przez oddziaływania na przebieg procesów i zjawisk dla osiągnięcia założonych celów [Griffin 1996, s. 34], stanowi ważny element wszystkich organizacji. Każda z nich potrzebuje go - niezależnie od tego, czy używa tego terminu, czy też nie [Drucker 2011, s. 163, 164]. Wszystkie organizacje muszą bowiem myśleć o rezultatach, definiować cele i układać strategie, jakimi środkami przekształcić je w wyniki. Zarządzanie odbywa się na trzech głównych poziomach - strategicznym, taktycz- 
nym i operacyjnym [Aldag, Stearns 1991, s. 56] i wymaga skoordynowanych działań - ekspertów, menedżerów i przywódców [Hausner 2014, s. 273].

Lata 80. i 90. ubiegłego wieku to w zachodniej literaturze naukowej okres wzmożonej popularności koncepcji Nowego Zarządzania Publicznego (New Public Management). Koncepcja ta, sprowadzająca się w dużym skrócie do adaptacji sposobów zarządzania obowiązujących w sektorze prywatnym do sektora publicznego, stała się na początku nowego wieku nie mniej popularna również w polskiej literaturze przedmiotu. Menedżerskie podejście do administracji publicznej zaczęło wdrażać państwo na szczeblu centralnym, jak też podmioty je tworzące - w tym jednostki samorządu terytorialnego (dalej JST). Koncepcja nie okazała się remedium na wszystkie problemy pojawiające się w sektorze publicznym. Sprawiła jednak, że instytucje publiczne zaczęły coraz częściej zwracać uwagę na efektywność, a więc być bardziej zorientowane na wyniki.

Pośród różnych zasobów szczególną rolę odgrywają środki finansowe. Ważnym elementem zarządzania jest więc zarządzanie finansami. Zarządzanie finansami publicznymi łączy w sobie podejście technokratyczne z podejściem społecznym - inżynierię finansową z inżynierią społeczną [Postuła 2017, s. 12]. Złożony kompromis społeczno-polityczny powoduje, że wyniki często są dość odległe od tego, co mogłoby sugerować podejście czysto ekonomiczne. Jak słusznie zauważa A.K. Koźmiński [2014, s. 330], w sektorze publicznym trzeba brać pod uwagę większą wiązkę celów oraz wskaźników. Zarządzanie przez rezultaty i efektywność finansowania zadań publicznych nie są jedynie elementami ewolucji w podejściu do wykonywania zadań publicznych, według części badaczy są one również standardem zarządzania w sektorze publicznym przez wiele krajów [Marchewka-Bartkowiak, Wiśniewski 2015, s. 205].

Istotnym elementem zarządzania finansami pozostaje zarządzanie długiem. Według K. Marchewki-Bartkowiak [2008, s. 22] istotą zarządzania długiem (dalej również ZD) jest duży zakres działań operacyjnych nakierowanych na realizację przyjętych celów wykonywanych w imieniu i pod nadzorem władz publicznych. Poza dość powszechnym postulatem przyjmowania korzystnych warunków jego obsługi [Gonet 2006, s. 238] i spłaty M. Cilak [2013, s. 205] jako istotę ZD wskazuje różnorodne działania prowadzące do zmniejszania się zadłużenia. Jako podstawowe ogniwa ZD wskazywane są kontrola kosztów obsługi i ryzyka z nim związanego. Te kwestie wydają się najistotniejsze z punktu widzenia opisywanego procesu na poziomie operacyjnym.

Kolejnym poziomem zarządzania jest poziom taktyczny. Wydaje się, że do tego poziomu odnosi się wiele definicji ZD zawartych w literaturze. Celem ZD jest pozyskanie środków pożyczkowych w odpowiedniej wielkości i odpowiednim czasie, przy zachowaniu akceptowalnych $\mathrm{w}$ danym podmiocie poziomów ryzyka [Bitner i in. 2013, s. 13, 14]. Działania, jakie składają się na opisywany proces, dotyczą planowanego zaciągnięcia i spłaty, zgodnie z potrzebami i możliwościami finansowymi [Bitner 1999, s. 23], jak też minimalizowania ryzyka utraty płynności i niewypłacalności oraz kosztów wykorzystania długu [Dylewski 2003, s. 55]. M. Jastrzębska [2009, s. 87, 88] wskazuje następujące jego etapy: planowanie poziomu 
w zależności od potrzeb i możliwości, organizowanie, motywowanie i monitorowanie. Harmonogram działań wskazuje M. Poniatowicz [2005, s. 252]: analiza sytuacji ekonomiczno-finansowej, określenie przyczyn korzystania, delimitacja celów zadłużenia, określenie funkcjonujących ograniczeń jak też maksymalnego jego poziomu, dywersyfikacja kanałów dystrybucji i monitoring (zarówno długu, jak i jego skutków).

Pomimo że wskazane powyżej definicje formułowane były w odstępie kilku, a nawet kilkunastu lat, uzasadniony wydaje się pogląd, że są one dość zbliżone, a ewentualne różnice wynikają w znacznej części z tego, że dotyczą różnego poziomu zarządzania, nawet jeśli sami autorzy definicji nie artykułują tego w sposób wyraźny. Trzeba jednak dodać, że dotyczą one przede wszystkim poziomów operacyjnego i taktycznego, a więc odnoszą się zarazem do działań operacyjnych i taktycznych. Z punktu widzenia długookresowego zrównoważenia kluczowe znaczenie może mieć zaś poziom (i działania) strategiczny. Do tego poziomu nawiązują M. Poniatowicz i in. [2010, s. 71] wskazując, że mianem efektywnego zarządzania długiem można określić proces decyzyjny optymalny również z punktu widzenia pożądanego modelu rozwoju lokalnego lub regionalnego.

\section{Zrównoważone zarządzanie długiem jako wyzwanie dla finansów publicznych}

W ostatnich kilkudziesięciu latach koncepcja rozwoju zrównoważonego stała się wyjątkowo popularna - zarówno w dyskursie naukowym, jak i w sensie deklaratywnym [Słodowa-Hełpa 2013, s. 36]. Równoważenie wymiarów ekonomicznych, społecznych i ekologicznych [Poskrobko 2001, s. 99] jest oczywiście dalece niewystarczające, stąd też tej filozofii rozwoju nadawano dodatkowe atrybuty - trwałości, samopodtrzymywania i zbilansowania [Czaja 2011, s. 277]. Duża popularność zagadnienia powodowała, że teoria się rozwijała. W wyniku jej ewolucji coraz częściej padały głosy, że rozwoju nie można redukować do zrównoważonego wyłącznie w trzech wspomnianych wymiarach - poszukiwać należy rozwiązań umożliwiających harmonizowanie celów rozwojowych we wszystkich sferach bytu ludzkiego [Woźniak 2015, s. 195-197]. Do badań nad rozwojem włączano więc pojęcie ładu zintegrowanego, rozumianego jako układ docelowy rozwoju zrównoważonego [Słodowa-Hełpa 2015, s. 84]. Pomimo dużej dynamiki zmian w zakresie teorii rozwoju zrównoważonego wydaje się, że ciągle zbyt mały nacisk kładziony jest na aspekt zrównoważenia finansowego $\mathrm{w}$ długim okresie. Zdarzenia mające miejsce na początku obecnego wieku w Grecji jednoznacznie wskazały, że rozwoju opartego na nadmiernym zadłużeniu nie można określić, ani zrównoważonym [Galbraith 2016, s. 237], ani pożądanym. Pożyczone fundusze mogą oczywiście przynieść zyski przewyższające negatywne konsekwencje; wielokrotnie tak się właśnie dzieje. Konieczne jest jednak uwzględnienie wszystkich implikacji danej decyzji - co niestety nie zawsze się zdarza [Hazlitt 2012, s. 175], problem trzeba bowiem widzieć w całości, a nie we fragmentach [Hazlitt 2012, s. 181]. 
Ocena zasadności zaciągania długu publicznego jest przedmiotem dyskusji ekonomistów różnych szkół. Jednoznaczne stanowisko względem długu cechuje klasyków oraz keynesistów. Według szkoły klasycznej nierównowaga budżetowa i związane $\mathrm{z}$ nią zadłużenie powinno być stanem wyjątkowym. Zdaniem J.M. Keynesa deficyt budżetowy wpływa na wielkość popytu i oddziałuje na procesy wzrostu gospodarczego. Na neutralność długu publicznego wskazują z kolei D. Ricardo oraz R. Barro nawiązujący do ricardiańskiego teorematu równoważności [Jajko 2008, s. 10-13]. Najbardziej dobitnym przykładem skali i skutków nadmiernego zadłużenia są państwa Unii Europejskiej należące do grupy PIGS, a także Belgia, Hiszpania czy Włochy. W okresie postkryzysowym 2008+, 23 państwa UE objęte zostały procedurą nadmiernego deficytu, a pięć z nich korzystało z programów pomocowych (Grecja, Irlandia, Portugalia, Rumunia i Łotwa) [Gadomski 2012]. Obecnie w opinii Komisji Europejskiej pięć państw UE może nie wypełniać reguł Paktu Stabilności i Wzrostu (Austria, Francja, Włochy, Belgia, Portugalia, Słowenia). Włochy, tuż po Grecji, mają najwyższy w UE dług przekraczający 130\% PKB. Hiszpania i Francja są obecnie objęte procedurą nadmiernego deficytu, a w stosunku do budżetu Rumunii KE zgłosiła poważne zastrzeżenia [Business Insider 2017].

Negatywne konsekwencje nadmiernego zadłużenia implikują pytanie dotyczące podejścia do zarządzania długiem publicznym w tradycyjnym i zrównoważonym paradygmacie finansów. O ile w tradycyjnym paradygmacie finansów kwestia równowagi budżetowej i zadłużenia postrzegana jest wyłącznie w ujęciu ekonomicznym, o tyle w finansach zrównoważonych kategoria ta traktowana jest szerzej (tab. 1).

Tabela 1. Zarządzanie długiem w tradycyjnym i zrównoważonym paradygmacie finansów

\begin{tabular}{|l|l|}
\hline \multicolumn{1}{|c|}{ Tradycyjny paradygmat finansów } & \multicolumn{1}{c|}{ Zrównoważony paradygmat finansów } \\
\hline Minimalizowanie kosztów obsługi długu & Minimalizowanie negatywnych efektów zadłużenia \\
\hline Zapewnienie płynności & Zapewnienie stabilności i bezpieczeństwa finansowego \\
\hline Ekonomiczne koszty obsługi długu & Ekonomiczne i pozaekonomiczne koszty obsługi długu \\
\hline $\begin{array}{l}\text { Wpływ na realizację celów strategii } \\
\text { rozwoju }\end{array}$ & $\begin{array}{l}\text { Wpływ na realizację celów strategii zrównoważonego } \\
\text { rozwoju, w tym Celów Milenijnych (MDGs) }\end{array}$ \\
\hline $\begin{array}{l}\text { Sprawiedliwość międzypokoleniowa, } \\
\text { wymiar ekonomiczny } \\
\text { (międzypokoleniowe rozłożenie kosztów) }\end{array}$ & $\begin{array}{l}\text { Sprawiedliwość międzypokoleniowa, wymiar } \\
\text { ekonomiczny, społeczny, środowiskowy (dbałość } \\
\text { o zasoby w stanie niepogorszonym, inwestycje } \\
\text { społecznie odpowiedzialne itd.) }\end{array}$ \\
\hline $\begin{array}{l}\text { Ocena skutków zadłużenia na podstawie } \\
\text { wskaźników ekonomicznych }\end{array}$ & $\begin{array}{l}\text { Ocena skutków zadłużenia na podstawie wskaźników } \\
\text { ekonomicznych i pozaekonomicznych }\end{array}$ \\
\hline $\begin{array}{l}\text { Tradycyjne instrumenty finansowe } \\
\text { w strukturze finansowania }\end{array}$ & $\begin{array}{l}\text { Zrównoważone instrumenty finansowe w strukturze } \\
\text { finansowania }\end{array}$ \\
\hline $\begin{array}{l}\text { Udział w finansowaniu społecznego } \\
\text { podziału pracy }\end{array}$ & Udział w finansowaniu dobrobytu społecznego \\
\hline $\begin{array}{l}\text { Wpływ na ekonomiczne decyzje } \\
\text { uczestników rynku }\end{array}$ & $\begin{array}{l}\text { Wpływ na ekonomiczne, społeczne i środowiskowe } \\
\text { decyzje uczestników rynku }\end{array}$ \\
\hline
\end{tabular}

Źródło: opracowanie własne. 
Finanse publiczne na każdym szczeblu powinny dążyć do długookresowej równowagi, co nie musi oznaczać zupełnego braku długu a jedynie doprowadzenie jego rozmiarów do bezpiecznego poziomu [Wyżnikiewicz 2010, s. 6]. Jednym z warunków niezbędnych do harmonizacji rozwoju oraz poprawy jakości życia staje się inkluzywność systemu społeczno-gospodarczego, rozumiana jako godzenie interesów społecznych, gospodarczych i ekologicznych przy równoczesnej optymalizacji wykorzystania potencjału społeczno-gospodarczego [Mączyńska 2016, s. 25]. Oznacza to potrzebę przechodzenia od gospodarki nadmiaru do gospodarki umiaru - również w zakresie zadłużenia. Ekonomia umiaru, to w ocenie G.W. Kołodki [2014, s. 172], dostosowywanie rozmiarów strumieni - ludzkich, naturalnych, finansowych i rzeczowych - do wymogu zachowania dynamicznej równowagi. Nieustanna troska o równowagę we wszystkich jej przekrojach jest kwestią o ogromnej wadze - chociaż wciąż tylko środek polityki, której celem jest rozwój [Kołodko 2014, s. 175]. Charakterystyczny dla współczesności ciągły wzrost aspiracji konsumpcyjnych pogłębia zadłużenie. Przyczyny nadmiernego zadłużenia mają oczywiście różne uwarunkowania, ich wspólnym mianownikiem jest jednak brak umiaru w wydatkach w relacji do dochodów [Pach 2016, s. 168]. W efekcie koncepcja państwa podatków ulega przekształceniu w państwo długu [Mączyńska, Pysz 2014, s. 241, 242]. Niewątpliwie w znacznej części przyczyną tego stanu rzeczy jest to, że politycy są niewolnikami cyklu wyborczego [Hausner 2014, s. 265]. Politycy - a więc decydenci odpowiedzialni za strategiczny poziom zarządzania długiem publicznym. Nikły efekt prób znaczącego podniesienia efektywności gospodarowania środkami publicznymi jest zaś w znacznej mierze ofiarą tego, że efektywność nie ma elektoratu [Mączyńska 2015, s. 30].

\section{Zakończenie}

Nadmierny dług publiczny kreuje zróżnicowane koszty i konsekwencje, nie tylko o charakterze ekonomicznym, ale przede wszystkim pozaekonomicznym. Tradycyjne podejście do zarządzania długiem publicznym za główny cel przyjmuje minimalizowanie kosztów obsługi długu, tymczasem w analizie skutków zadłużenia publicznego nie sposób pominąc kosztów społecznych, w tym w szczególności kosztów wykluczenia (w tym wykluczenia społecznego), które potęgowane jest jako zjawisko w warunkach nadmiernego zadłużenia.

Zarządzanie długiem publicznym nie jest zatem możliwe w oderwaniu od jego wymiaru społecznego i środowiskowego, zwłaszcza, że dług publiczny jest silnie powiązany z długiem sektora prywatnego, co potwierdziło doświadczenie kryzysu 2008+, który „rozlał” się na sektor finansów publicznych i wpłynął na wzrost długu publicznego. Silne powiązanie pomiędzy długiem sektora finansów publicznych i sektora prywatnego sprawia, że zrównoważone zarządzanie długiem zyskuje na znaczeniu. 
W kontekście podjętych rozważań znaczenia nabiera stwierdzenie I. Lipowicz [2017], która podkreśla, że konieczny jest powrót do władzy, w tym zarządzania publicznego, w kategoriach służby i zobowiązania do troski o powierzany depozyt państwa w swoistym kontrakcie pokoleniowym. Bez zrozumienia i wdrożenia w życie tych rad trudno będzie mówić o zrównoważonym zarządzaniu długiem publicznym. Postulaty te kierowane są przede wszystkim do decydentów odpowiedzialnych za strategiczny poziom zarządzania publicznego.

\section{Literatura}

Aldag R.J., Stearns T.M., 1991, Management, South-Western Publishing, Cincinnati, OH.

Bitner M., 1999, Gmina na rynku kapitałowym. Podstawy zarządzania dtugiem komunalnym, Agencja Rozwoju Komunalnego, Warszawa.

Bitner M., Cichocki K.S., Sierak J., 2013, Standardy zarządzania dtugiem na szczeblu lokalnym i regionalnym oraz ich wpływ na finansowanie infrastruktury, Polska Akademia Nauk, Instytut Badań Systemowych, Warszawa.

Business Insider, 2017, Dług Włoch budzi strach Komisji Europejskiej. Pod lupa sa też budżety 5 innych państw, https://businessinsider.com.pl/finanse/makroekonomia/budzety-szesciu-panstwmoga-lamac-wymogi-unii-europejskiej/29jet5v (4.09.2018).

Cilak M., 2013, Instrumenty wspierania rozwoju gospodarczego stosowane przez samorzad terytorialny. Problematyka prawnofinansowa, TNOiK Dom Organizatora, Toruń.

Czaja S., 2011, Czas w ekonomii, Wydawnictwo Uniwersytetu Ekonomicznego we Wrocławiu, Wrocław.

Drucker P., 2011, O zarządzaniu, społeczeństwie i gospodarce, MT Biznes, Warszawa.

Dylewski M., 2003, Kierunki zarządzania długiem jednostek samorząu terytorialnego - analiza i podstawy metodologiczne, Finanse Komunalne, nr 6, s. 49-60.

Gadomski W., 2012, Europa w procedurze nadmiernego deficytu, Obserwator Finansowy, 28.02.2012, https://www.obserwatorfinansowy.pl/tematyka/makroekonomia/europa-w-procedurze-nadmiernego-deficytu/ (4.09.2018).

Galbraith J.K, 2016, Witamy w zatrutym kielichu. Grecki kryzys a przyszłość Europy, Wydawnictwo Naukowe PWN, Warszawa.

Gonet W., 2006, Kredyty, pożyczki, obligacje w gospodarce finansowej samorząu terytorialnego, Szkoła Główna Handlowa w Warszawie, Oficyna Wydawnicza, Warszawa.

Griffin R.W., 1996, Podstawy zarządzania organizacjami, Wydawnictwo Naukowe PWN, Warszawa.

Hausner J., 2014, Globalny kryzys: potrzeba nowej polityki gospodarczej, Ekonomista, nr 2, s. 249-274.

Hazlitt H., 2012, Ekonomia w jednej lekcji, Instytut Ludwiga von Misesa, Warszawa.

Jajko B., 2008, Dlug publiczny a równowaga fiskalna. Czy i kiedy rząd powinien emitować dług publiczny?, CeDeWu, Warszawa.

Jastrzębska M., 2009, Zarządzanie dtugiem jednostek samorządu terytorialnego, Wolters Kluwer business, Warszawa.

Jurewicz D., 2018, Financial Sustainability of Local Government, Zeszyty Naukowe Wyższej Szkoły Bankowej w Poznaniu nr 1(78), s. 103-116.

Kołodko G.W., 2014, Nowy pragmatyzm, czyli ekonomia i polityka dla przyszłości, Ekonomista, nr 2 , s. $161-181$.

Koźmiński A.K., 2014, Przedsiębiorcze państwo?, Ekonomista, nr 2, s. 321-336. 
Lipowicz I., 2017, Dobro wspólne, Ruch Prawniczy, Ekonomiczny i Socjologiczny, nr 3, s. 17-31.

Marchewka-Bartkowiak K., 2008, Zarzadzanie długiem publicznym. Teoria i praktyka państw Unii Europejskiej, Wydawnictwo Naukowe PWN, Warszawa.

Marchewka-Bartkowiak K., Wiśniewski M., 2015, Obligacje społeczne - nowy instrument finansowania zadań społecznych, Studia BAS, nr 4, s. 205-222.

Mączyńska E., 2015, Wybrane globalne i makroekonomiczne czynniki kształtujace w Polsce dochodzenie praw z umów, Biuletyn PTE, nr 1, s. 21-31.

Mączyńska E., 2016, Ochrona praw wierzycieli w kontekście makroekonomicznych asymetrii, Biuletyn PTE, nr 4, s. 13-25.

Mączyńska E., Pysz P., 2014, Liberalizm, neoliberalizm, ordoliberalizm, Ekonomista, nr 2, s. 221-242.

Pach J., 2016, Umiar $w$ finansach publicznych $w$ świetle kryteriów budżetowych z Maastricht, [w:] Pach J. i in. (red.), Ekonomia umiaru. Realna perspektywa? Nowy paradygmat Grzegorza W. Kotodki, Wydawnictwo Naukowe PWN, Warszawa, s. 155-171.

Poniatowicz M., 2005, Dlug publiczny w systemie finansowym jednostek samorzadu terytorialnego (na przykładzie miast na prawach powiatu), Wydawnictwo Uniwersytetu w Białymstoku, Białystok.

Poniatowicz M., Salachna J.M., Perło D., 2010, Efektywne zarządzanie dlugiem w jednostce samorzadu terytorialnego, Wolters Kluwer business, Warszawa.

Poskrobko B., 2001, Podstawy polityki ekologicznej, [w:] Górka K., Poskrobko B., Radecki W. (red.), Ochrona środowiska. Problemy społeczne, ekonomiczne i prawne, PWE, Warszawa.

Postuła M., 2017, Finanse publiczne w architekturze globalnej gospodarki. Teoria a polska praktyka gospodarcza, Difin, Warszawa.

Słodowa-Hełpa M., 2013, Rozwój zintegrowany. Warunki, wymiary, wyzwania, CeDeWu, Warszawa.

Słodowa-Hełpa M., 2015, Interdyscyplinarna natura paradygmatu rozwoju-uwarunkowania i propozycje usprawnienia dialogu, Nierówności Społeczne a Wzrost Gospodarczy, nr 41, s. 67-92.

Woźniak M.G., 2015, O niektórych problemach wspótczesnego człowieka, ekonomii i systemów ekonomicznych w kontekście integracji procesów rozwojowych, Nierówności Społeczne a Wzrost Gospodarczy, nr 41, s. 195-213.

Wyżnikiewicz B., 2010, Dlugofalowe równoważenie finansów publicznych. Wprowadzenie, Instytut Badań nad Gospodarką Rynkową, Warszawa. 